\title{
Penelitian Arkeologi Dalam Konteks Pengembangan Sumberdaya Arkeologi
}

\section{Bugie M.H. Kusumohartono}

Keywords: methods, practice, theory, archaeology, research, cultural resource management, CRM

\section{How to Cite:}

Kusumohartono, B. M. H. (1993). Penelitian Arkeologi Dalam Konteks Pengembangan Sumberdaya Arkeologi. Berkala Arkeologi, 13(2), 46-57. https:/ / doi.org/10.30883/jba.v13i2.576

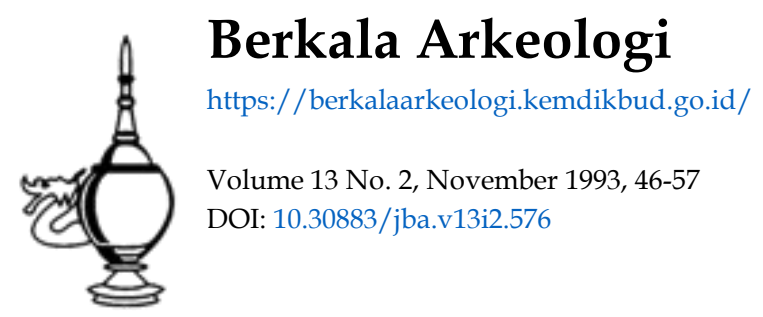




\title{
PENELITIAN ARKEOLOGI DALAM KONTEKS \\ PENGEMBANGAN SUMBERDAYA ARKEOLOGI'
}

\author{
Bugie Kusumohartono \\ (Balai Arkeologi Yogyakarta)
}

\section{PERMASALAHAN DI DEPAN MATA}

Upaya mengungkapkan dan menjelaskan manusia serta kebudayaan dalam rentang dan proses masa lampau ke masa kini, melalui tinggalan- tinggalan bendawinya, adalah tantangan yang dihadapi bidang arkeologi di setiap negara. Namun dalam dinamika interaksi antar dan lintas sektoral saat ini, tentu saja tantangan sektor arkeologi juga semakin berkembang. Dunia arkeologi berada dalam proses tarik-ulur konflik kepentingan antar sektor. Sementara itu,dalam negara-negara dunia ke 3 terdapat kecenderungan konflik-konflik seperti tersebut di atas berorientasi ekonomik.

Dalam proses semacam ini, aktivitas yang meproduksi (industri) barang dan jasa memiliki bargaining position yang jauh lebih unggul dari pada industri yang memproduksi pengetahuan (knowledge). Implikasinya adalah bahwa dalam kebijakan pembangunan ekonomi yang biasanya berjangka pendek, sumberdaya yang digunakan untuk memproduksi pengetahuan, cenderung dikesampingkan dalam proses pengambilan keputusan. Dalam situasi inilah kita memahami berlangsungnya penurunan kualitas atau bahkan punahnya berbagai warisan budaya di tanah air.

Apabila kecepatan dari penurunan kualitas tersebut dapat didampingi oleh intensitas penelitian arkeologi yang seimbang, maka bagi kepentingan studi arkeologi, fenomena ini "masih dapat" ditolerir. Masalahnya secara faktual kemampuan penelitian arkeologi di Indonesia dari berbagai segi masih sangat kurang dibanding dengan akumulasi warisan budaya di seluruh tanah air. Oleh karenanya upayaupaya penyelamatan data arkeologi di Indonesia perlu mendapatkan perhatian utama untuk dikembangkan dan dimasyarakatkan. Dengan upaya-upaya semacam itu diharapkan penelitian-penelitian arkeologi di

\footnotetext{
- Pernah disajikan dalam Lokakarya Tentang Penelitian, Amdal, dan Pelestarian Sumberdaya Arkeologi, di Balai Arkeologi Yogyakarta, tgi. 10 - 11 Maret 1993.
} 
masa depan -- dengan dukungan iptek yang semakin canggih -- masih berkesempatan mencicipi data arkeologi yang masih tersisa.

Secara sederhana dapat dinyatakan bahwa penelitian arkeologi bertujuan untuk memproduksi pengetahuan mengenai masa lampau. Dorongan untuk memahami masa lampaunya memang merupakan sifat unik dari homo sapien karena masa lalu adalah kompenen penting dari kehidupan masa kini (Cleere, 1989:5-6). Oleh karenanya upaya untuk menelusuri masa lalu merupakan hak asasi setiap manusia (McGimsey, 1972:5).

Dengan prinsip di atas sebagai landasan maka pada dasarnya pengelolaan warisan budaya harus diorientasikan, atau bahkan melayani, keinginan-keinginan masyarakat. Menyambung opininya tersebut, Cleere (1989:10) menekankan bahwa:

"... the public must be seen as the body of taxpayers whose money is being used in its name to finance antiquities services, survey and excavation, compensation for talking monuments out of cultivation, tehe conservation, presentation and promotion of monuments, and much more."

Secara lebih ekstrim Macleod (1977) mengekspresikan pentingnya faktor aspirasi masyarakat, melalui semboyannya yang terkenal yaitu "peddle or perish". Minat kepentingan masyarakat harus mendapat perhatian utama dalam pengelolaan sumberdaya budaya. Menurutnya ada korelasi positif antara intensitas kemanfaatan warisan budaya dengan kebijakan mengucurnya anggaran biaya bagi pelestarian dan penelitian arkeologi.

Apabila dirumuskan secar singkat, maka pengelolaan warisan budaya pada dasarnya ditentukan oleh tiga kepentingan pokok (Cleere, 1989:5-10). Pertama, kepentingan ideologik guna memanfaatkan identitas budya, yang berkaitan erat dengan fungsi-fungsi pendidikan. Kedua, kepentingan akademik, terutama dalam hal penyelamatan sumber-sumber data bagi pengembangan penelitian arkeologi. Ketiga adalah kepentingan ekonomik dalam hubungannya dengan kepariwisataaan. Ketiganya saling terkait, sehingga bagaimanapun juga wawasan peneliti arkeologi tidak boleh dilepaskan dari aspek kepentingan ideologik dan ekonomik. 


\section{DUKUNGAN ANTAR SEKTOR TERKAIT}

Berikut akan diulas secara singkat beberapa hal yang berkaitan dengan tuntutan, kecenderungan implementasi, dan permasalahn yang berkembang pada dekade terakhir ini dalam pengelolaan warisan budaya oleh berbagai sektor pembangunan. Paparan di bawah diharapkan dapat menggambarkan seberapa jauh tantangan yang dihadapi oleh produk penelitian arkeologik untuk mendukung kepentingan sektor terkait tersebut.

\section{Kepentingan Ideologik}

Berakhirnya kolonialisme dan kebangkitan nasionalisme di berbagai bekas negara terjajah telah mendorong peranan yang positif dari warisan budaya, khususnya yang bersifat bendawi, di dalam kehidupan bangsa-bangsa tersebut. Berbagai aktivitas penelitian arkeologis diarahkan hasilnya untuk dapat mengatasi diskontinyuitas budaya yang diakibatkan oleh kolonialisme. Pada hasil-hasil penelitian arkeologis tersebut diletakkan harapan agar jatidiri budaya bangsa direkonstruksi, sebagai landasan persatuan dan kebanggaan nasional. Pada wujudnya yang paling ekstrim adalah seperti ditunjukkan oleh bekas negara Rhodesia, yang menggunakan nama monumen arkeologiknya yang terbesar sebagai nama negara, yaitu Zimbabwe. Sebaliknya kebanggaan nasional banyak disandarkan kepada aspek budaya yang lain seperti bahasa (Cleere, 1989:8).

Namun bagian akhir pendapat Cleere tersebut tidak sepenuhnya akurat. Richard I. Ford menunjukkan bahwa di kalangan negara kolonial terdapat gejala bahwa nasionalisme tumbuh bersamaan dengan perhatian yang besar pula pada studi prasejarah. Bahkan ada satu fase ketika hasil-hasil penelitian arkeologik dimanfaatkan sebagai bahan propaganda politik, sehingga muncul istilah nationalistic archaeology, atau political archaeology (Ford, 1973:84-85).

Ketika pergolakan politik mendominasi dunia, kepentingan ideologik secara berlebihan tersebut pernah mendominasi perkembangan arkeologi. Sisi negatif dari political archaeology adalah peranannya sebagai sarana legitimasi terhadap supremasi ras Arya dalam ideologi Nazi dan landasan fasisme di Italia (Ford, 1973:86-87).

Tuntutan terhadap sumbangan dan peranan warisan budaya dalam pemantapan jatidiri, belakangan ini mendapatkan pula muaranya pada gagasan-gagasan yang berkaitan dengan aktivitas pembangunan 
kota (urban development). Keprihatinan sehubungan dengan melunturnya jatidiri kota didasari oleh perkembangan dan perubahan ekonomi yang sangat cepat, sehingga mempengaruhi lingkungan tertentu yang berfungsi sebagai simbol jatidiri kota. Oleh karena itu dalam perspektif yang luas (Ananim, 1990:52, v), Hidehiko Sazanami (direktur UNCRD) menyatakan pada konfrensi mengenai kota-kota perbukitan dengan fokus pada kota-kota lokal, bahwa:

It has been recognized that it is importance to revitalize local cities to serve as regional cores for the purpose of supporting sustainable and balanced development in the future. Towards this goal, the natura/ characteristice of such cities should be utilized to their fullest as environmental resources while, at the same time, traditional and historical aspects should be preserved to add to each city's unique qualities.

Warisan budaya yang diperhatikan dalam fokus ini adalah bentang lahan budaya (tradisional atau bersejarah) yang berperan sebagai pembentuk struktur fisik desa atau kota, atau yang sering juga disebut dengan historic landscape (Anonim, 1988). Sudah muncul pemahaman di antara para perencana kota mengenai pentingnya melestarikan obyek-obyek warisan budaya semacam itu dalam penataan kota (urban design guidelines), dengan mensyaratkan perhatian pada pengidentifikasian dan penyelarasan pembangunan terhadap karakter khas rancangan luar (design exterior atau facade) yang telah dimiliki suatu bagian kota. Lebih dari itu, pembangunan di sekitar bagian kota yang bernilai sejarah dirancang untuk tetap bersifat komplementer (Knipfel dkk., 1987:5-6). Di Indonesia belakangan ini, penyusunan Rencana Tata Ruang Kota (RTRK) dan Rencana Tata Bangunan (RTB) mulai lebih didasarkan pada wawasan budaya (Koesoemo, t.th.: 13). Dengan demikian dukungan kemampu an arkeologi semakin diperlukan.

Dengan didasari oleh prinsip di atas, proses perancangan kota tidak selalu berkonotasi menciptakan sesuatu yang baru. Dalam perencanaan kota selalu terdapat nafas pelestarian, khususnya terhadap keberadaan berbagai warisan budaya. Di dalam kepentingan kota secara keseluruhan, manajemen perawatan lingkungan binaan atau historic presevation ini memberikan tekanan yang besar terhadap azas manfaat (adaptative use) dari warisan budaya yang bersangkutan. $\mathrm{Di}$ samping mempertahankan citra preservation juga berfungsi meningkatkan efisiensi, mengingat biaya, energi, dan lahan yang digunakan dalam pembangunan kota dapat lebih dihemat (Fitch, 
1982:1-3). Selain untuk kepentingan fasilitas pemerintahan, obyek warisan budaya kota merupakan atraksi budaya yang sangat menarik bagi pariwisata (Wiener, 1980:188-190).

Dalam kasus-kasus perencanaan kota semacam inilah maka penelitian arkeologik dituntut sumbangannya. Tuntutan tersebut semakin kuat mengingat pendekatan terbaru yang digunakan dalam proses perencanaan kota didasari oleh studi lingkungan - prilaku (Environment - Behavior Studies = EBS). Pemanfaatan studi tersebut, menurut Amos Rapoport, di antaranya didasari oleh studi arkeologi yang berhasil mempelajari keterkaitan lingkungan binaan - budaya bendawi - bentang lahan budaya, untuk memahami perilaku manusia masa lampau. Pengetahuan itu kemudian diujikan pada konteks masa kini untuk dimanfaatkan secara aplikatif dalam proses perancangan kota (Rapoport, 1990).

\section{Kepentingan Ekonomik}

Rumusan-rumusan identitas budaya di atas dapat diwariskan dari generasi ke generasi melalui aktivitas pendidikan. Dalam kegiatan itulah obyek warisan budaya tersebut kembali berperan sebagai media yang berfungsi sebagai saran pewarisan. Kunjungan ke situs arkeologi atau museum juga dinilai berhasil menanamkan pemahamanpemahaman kesejarahan pada siswa-siswa sekolah sejak usia muda (Cleere, 1989:9). Hanya saja masalahnya, fungsi semacam itu menuntut kemasan khusus guna mendukung efektivitas komunikasi pengajaran, namun pada umumnya berada di luar gagasan para pengelolanya.

Pada hakekatnya aktivitas kunjungan siswa sekolah ke berbagai obyek warisan budaya adalah bagian dari kepariwisataan, dalam hal ini wisata budaya. Wisata budaya sendiri tidak terbatas pada kunjungan masa manusia pada obyek-obyek monumental dan balai- balai seni semata (Cleere, 1989:9), namun juga meliputi minat pada museummuseum antropologi dan arkeologi, bagian-bagian kota yang bersejarah, festival-festival kesenian dan upacara tradisional, maupun berbagai benda kerajinan dan cinderamata yang berbau khas tradisi lokal (De Kadt, 1979:15).

De Kadt melihat bahwa pariwisata budaya mulai tumbuh sejak PDIl, bersamaan dengan semakin intensifnya informasi mengenai berbagai keunikan negara jajahan ke Eropa dan Amerika. Selaras dengan itu, negara-negara merdeka baru yang sedang berupaya 
mengakumulasikan modal dan dana untuk pembangunan, berlombalomba mencari devisa sebanyak-banyaknya (Collins, 1990).

Pariwisata sangat berkaitan dengan quality of experiences atau mutu dari pengalaman wisatawan di daerah kunjungan wisata. Semakin tinggi mutu dari pengalaman tersebut berarti semakin tinggi pula nilai jual obyek wisata yang bersangkutan. Mutu dari pengalaman wisatawan biasanya tidak jauh dari obyek-obyek yang bersifat unik dan lokal. Keunikan dan kelangkaan antara lain dapat diperoleh melalui obyekobyek arkeologik serta penjelasan- penjelasan budaya di baliknya.

Di lain pihak, pelestarian atas berbagai ragam bentuk budaya bendawi tradisional dan kuna, sangat bermanfaat sebagai acuan ide-ide pengembangan motif-motif kerajinan dan cenderamata lokal (De Kadt, 1979:15). Pada akhirnya pariwisata melalui pengembangan sumberdaya budaya akan sangat banyak memberikan kontribusi dalam pembangunan ekonomi regional (Braden dan Wiener, 1980).

\section{Kepentingan Akademik}

Mungkin selama ini pembangunan kepariwisaan dalam kaitannya dengan keberadaan warisan budaya nasional lebih dipahami pada sisi dan dampak negatif yang ditimbulkannya. Namun di sisi lain interaksi di antara keduanya dapat menghadirkan kecenderungan yang positif, terutama bagi sumberdaya budaya itu sendiri. Dalam kecenderungan pariwisata budaya pada dekade terakhir ini, quality of resources atau kualitas sumberdayanya merupakan tuntutan dari wisatawan. Semakin "asli" dan lestari obyeknya, semakin potensial pula perkembangannya (Collins, 1990).

Pada mulanya pariwisata budaya global berkembang dalam era mass tourism. Dalam era ini, keberhasilan perencanaan pariwisata budaya selalu ditunjukkan pada angka-angka jumlah wisatawan yang datang. Era ini menghadirkan segmen wisatawan "pemburu", baik yang bergerak di lingkungan peninggalan sejarah-arkeologi maupun yang bergerak di lingkungan kehidupan masyarakat tradisional- etnik. Segmen ini tidak puas hanya dengan sekedar dokumentasi foto atau postcard semata, namun cenderung mengejar cinderamata eksklusif, misalnya elemen arca dari sebuah runtuhan candi atau jumat pusaka yang dimiliki oleh suatu masyarakat "primitif" (Graburn, 1989:32-33).

Sebagai reaksi dari era mass tourism yang berorientasi pada kuantitas tersebut, belakangan ini muncul era baru yang didasari oleh semangat small scale tourism atau green tourism sebagai alternatif 
pariwisata tipe baru (Nuryanti, 1991:3). Gagasan dibalik tipe yang baru ini dianggap tepat pada era di mana perhatian terhadap kelestarian lingkungan dan sumberdaya menjadi dimensi prioritas global.

Pariwisata tipe baru ini menekankan pada "keaslian" dan kelestarian sumberdaya budaya (Collins, 1990), proses seleksi pada tipe wisatawan yang datang, serta pemahaman mengenai ambang daya dukung lingkungan budaya setempat (De Kadt, 1979:345-346).

Sementara itu suatu penelitian mengenai sikap masyarakat sekitar terhadap suatu obyek warisan budaya, memperlihatkan adanya korelasi positif dengan manfaat yang dipetik oleh masyarakat bersangkutan dari kunjungan wisatawan ke daerahnya. Artinya, tingginya "nilai jual" suatu warisan budaya sebagai obyek pariwisata yang diikuti oleh tingginya manfaat yang dipetik oleh masyarakat sekitar dari kunjungan wisatawan akan mendorong tumbuhnya sikap dan per-sepsi yang positif dari masyarakat sekitar tersebut terhadap warisan budaya yang memberi mereka manfaat (Anonim, 1980/1981). Pada masyarakat sekitar tersebut tercermin adanya rasa memiliki, yang me-rupakan modal utama bagi pembinaan program public archaeology selanjutnya.

Dengan demikian kelestarian sumberdaya arkeologik bukanlah semata-mata merupakan tuntutan para arkeolog semata, namun juga tuntutan sektor lain. Satu contoh lain patut dikemukakan di sini, bahwa Pemerintah Daerah Kodya Yogyakarta, khususnya Dinas Pekerjaan Umum (Cipta Karya), mencanangkan adanya kawasan konservasi di dalam Rencana Induk Kota Yogyakarta. Ditetapkan tiga kawasan budaya yang harus dilestarikan, yaitu Kawasan Malioboro,, Kawasan Keraton, Kawasan Pakualaman, dan Kawasan Kotagede.

Gagasan pelestarian tersebut tidak berasal dari arkeolog, walaupun produk dari gagasan tersebut penting bagi penerapan penelitian urban archaeology. Bagi kepentingan masyarakat, tiga konservasi tersebut merupakan bukti fisik dari akar sejarah dan budaya Yogyakarta (Mataram) lama, sehingga menjadi salah satu elemen penting dari jatidiri kota. Kasus-kasus semacam ini dapat pula ditemui dan dikembangkan di kota-kota lain.

\section{MEMPERBARUI ORIENTASI PENELITIAN}

Dari uraian di atas nampak jelas bahwa perencanaan pembangunan di tiap sektor penting didekati dengan kerangka yang holistik. Sehingga layak atau tidaknya suatu rencana pembangunan, tidak cukup 
didekati hanya dengan pertimbangan biaya dan teknologi semata (Soemarwoto, 1989), namun juga pertimbangan lingkungan (hi-dup). Pendekatan lingkungan mewakili kepentingan berbagai sektor dan sumberdaya yang terkait, termasuk di dalamnya sektor kebudayaan dan sumberdaya arkeologik.

Penapisan terhadap kelayakan rencana-rencana proyek dengan pendekatan lingkungan tersebut secara formal diwadahi oleh ketentuan Analisis Mengenai Dampak Lingkungan (AMDAL). Ketentuan payungan adalah UU No. 4/1982, dan ketentuan pelaksananya adalah PP No. 29/1986. UU No. 4/1982 tersebut tidak hanya menjadi payung bagi PP No.51/1993, namun juga menjadi payung bagi berbagai ketentuan yang lain seperti ketentuan tentang benda cagar budaya (UU No. 5/1992), pariwisata (UU No. 9/1990), tataruang (UU No. 24 1992), pelestarian alam (UU No. 5/1967; UU No. 5/1990), dan lain sebagainya.

Harapan ideal dari adanya mekanisme tersebut adalah terselenggaranya kegiatan pembangunan yang tidak saling mengorbankan kepentingan sektor/sumberdaya yang lain. Bagaimanapun juga patut diingat bahwa setiap sektor dan sumberdaya merupakan asset yang dengan caranya masing-masing bermanfaat bagi masyarakat. Oleh karena itu kegiatan pembangunan harus mempu pula meningkatkan kualitas dan nilai tambah dari asset yang terkait, dan bukan sebaliknya.

Prinsip ini merupakan salah satu aspek dalam kerangka pendekatan untuk menemukan dan menetapkan orientasi baru penelitian arkeologi Indonesia di masa depan. Orientasi baru tersebut penting mengingat pola penelitian arkeologi di Indonesia belum memberikan sumbangan yang efektif bagi kepentingan masyarakat (Anonim, 1993).

Sinyalemen tersebut antara lain dapat dilihat dari banyaknya penyusunan program penelitian arkeologi yang dilakukan secara parsial dan lebih didasarkan pada jenis minat dan tingkat kemampuan tertentu. Konsekuensi dari penyusunan program semacam itu tampak pada penyebaran penelitian yang secara spasial kurang merata, sehingga terjadi pemusatan pada beberapa daerah tertentu, serta kajian tema yang kurang proposional yang menyebabkan beberapa tema tertentu belum banyak diidentifikasi dan ditelaah.

Sebagai sebuah kegiatan yang strategis, penelitian arkeologi Indonesia belum memiliki rumusan kebijakan penelitian yang berlaku umum, baik yang bersifat akademik untuk pengembangan ilmu pengetahuan di bidang arkeologi, maupun yang non-akademik dalam kaitannya dengan kepentingan masyarakat. Dengan kondisi seperti tersebut 
di atas, maka hasil kerja maupun keberadaan kegiatan penelitian arkeologi kurang jelas peranan maupun sumbangannya di tengah masyarakat luas.

Oleh karena itu orientasi baru penelitian arkeologi harus didasari oleh elemen pendekatan kontekstual pada kepentingan masyarakat lokal, propinsial, dan nasional. Sementara itu dua elemen pendekatan yang lain adalah: 1) kebijakan nasional pengembangan kebudayaan, 2) kecenderungan akhir dari penelitian arkeologi global.

Orientasi semacam itu diaplikasikan dalam bentuk penelitian yang berangkat dari potensi, karakteristik, dan permasalahan setempat. Dengan demikian maka penelitian arkeologi akan memiliki makna dan tidak tercerabut dari akar lingkungan sosiainya. Terlebih bagi penelitian arkeologi di Indonesia yang mayoritas masih dibiayai oleh pajak masyarakat melalui APBN. Oleh karena itu orientasi pada kepentingan akademik, ideologik, dan ekonomik harus dilakukan secara berimbang.

Bersamaan dengan itu,sudah saatnya dikembangkan pula kepekaan para peneliti arkeologi terhadap permasalahn yang dihadapi oleh situs yang diteliti. Harus diakui bahwa secara kelembagaan-formal, studi tentang permasalahn situs arkeologi di dalam perspektif pengelolaan, merupakan tugas dari Ditlinbinjarah dan UPT-nya. Namun prioritas penanganan situs arkeologi bagi kepentingan publik (oleh Ditlinbinjarah) dan bagi kepentingan akademik (penelitian) tidak selalu berjalan seiring.

Sudah menjadi kewajiban moral bagi peneliti arkeologi untuk ikut berperanserta di dalam upaya pelestarian situs di dalam batas kemampuan dan wewenang yang ada. Hal itu dapat diwujudkan dalam bentuk pengidentifikasian dan pengkajian terhadap jenis kerusakan (dampak negatif yang menimpa) situs, faktor-faktor penyebab, dan rekomendasi berupa alternatif penanggulangannya (Anonim, 1992/1993; Kusumohartono, 1992/1993).

Hal ini dapat dilakukan oleh para peneliti karena -- terutama untuk kegiatan ekskavasi -- memiliki kesempatan untuk secara intensif melakukan observasi terhadap situs penelitiannya. Manfaat balik dari adanya kajian permasalahan situs secara terintegrasi di dalam penelitian arkeologi tersebut adalah secara signifikan mendukung pelestarian dan ketersediaan sumberdaya arkeologi setempat sebagai data bagi penelitian-penelitian berkelanjutan. 


\section{KEPUSTAKAAN}

Anonim, 1980/1981, Laporan Penelitian Sikap Masyarakat Terhadap Monumen Budaya. Kegiatan Riset Institusional Fakultas Sastra UGM - PPPT UGM (tidak diterbitkan).

Anonim, 1988, Section 630: Historic Landscapes, materi dalam SPAFA Training Course in Conservation of Ancient Cities and Settlement. 14 Agustus-12 November 1988.

Anonim, 1990, Hillside Cities, Raport and Summary of the Proceedings of the International Conference on Hillside Cities: Focus on the Revitalization of Local Cities. UNCRD Meeting Report Series, No. 39.

Anonim, 1992/1993, Laporan Hasil Penelitian Arkeologi Situs Wonoboyo, Gondang, Klaten, Jawa Tengah. Balai Arkeologi Yogyakarta.

Anonim, 1993 Tugas dan Fungsi Balai Arkeologi Yogyakarta Menghadapi PJP II. Balai Arkeologi Yogyakarta

Braden, Paul V. dan Loiuse Wiener, 1980, Bringing Travel, Tourism, and Cultural Resource Activities in Harmony with Regional Economic Development, dalam D.E. Hawkins dkk (ed.). Tourism Marketing and Management Issues. Washington, D.C.: George Washington University.

Cleere, H.F (ed.), 1989, Archaeological Heritage Management in the Modern World. London: Unwin Hyman.

Collins, Robertson E. 1990, Heritage and Tourism, Archaeology Worldwide, Federal Archaeology Report.

De Kadt, Emanuel, 1979, Tourism Passport to Development ?: Perspectives on the Social and Cultural Effects of Tourism in Developing Countries. Oxford University Press. 
Fitch, James Marston, 1982: Historic Preservation: Culturial Managemnet of the Built World. McGraw-Hill Book Company.

Ford, Richard I. 1973, Archaeology Serving Humanity, dalam C.L. Redman (ed.) Research and Theory in Current Archaeology. John Wiley \& Sons.

Graburn, Nelson H.H. 1989, Tourism: The Sacred Journey, dalam V.L. Smith (ed.). Hosts and Guests, The Anthropology of Tourism. Philadelphia: Univ. of Pennsylvania Press.

Knipfel, Carl (dkk.), 1987, Urban Design Guidelines. City of Scarborough Planning Departement (diterjemahkan oleh Felia Srinaga, 1989).

Koesoemo, Noer Saijidi M. (Direktur Tata Bangunan). t.th. Project Cycle Pengaturan dan Penataan Bangunan pada Kawasan Pemukiman dan Kawasan Strategis (Industri dan Pariwisata). Departemen PU. Ditjen Cipta Karya, Direktorat Tata Bangunan.

Kusumohartono, Bugie, 1988, Pengelolaan Sumberdaya Budaya dalam Perspectif Pelestarian Arkeologi dan Tata Laksana PP No. 29/1986 tentang AMDAL, prasaran dalam Seminar Sehari Perumusan Peranserta Arkeologi dalam Pelaksanaan AMDAL. di Yogyakarta, 5 Oktober 1986.

...-..-..-, 1992/1993, Laporan Hasil Penelitian Arkeologi Situs Medowo, Gampingrowo, Tarik, Sidoarjo, Jawa Timur. Balai Arkeologi Yogyakarta.

Macleod, Donald G. 1977, Peddle or Perish: Archaeological Marketing from Concept to Product Delivery, dalam Schiffer M.B. dan G.J. Gumerman (ed.). Conservation Archaeology. London: Academic Press.

McGimsey III, Charles R., 1972, Public Archaeology. New York: Seminar Press. 
Nuryanti, Wiendu, 1991, Perencanaan Pembangunan Pariwisata di Indonesia, Seminar Sosial Budaya Pengembangan Pariwisata, 16-17 Desember 1991. PUA IImu-ilmu Sosial UGM.

Rapport, Amos, 1990, History and Precedent in Environmental Design. New York: Plenum Press.

Soemarwoto, Otto, 1989, Analisis Dampak Lingkungan. Yogyakarta: Gadjah Mada University Press.

Wiener, Louise W., 1980, Cultural Resources: An Old Asset - A New Market for Tourism, dalam D.E. Hawkins dkk. (ed.). Tourism Marketing and Management Issues. Washington, D.C.: George Washington University. 